\title{
KOMPETENSI PROFESIONAL GURU DAN MOTIVASI KERJA DENGAN KINERJA GURU SMP NEGERI SE- KECAMATAN BILUHU KABUPATEN GORONTALO
}

\author{
Nikson A. Kadir Umar ${ }^{1}$ Muh. Hasbi ${ }^{2}$ Herson Anwar $^{3}$ \\ ${ }^{1}$ Sekolah Menengah Pertama Negeri Biluhu \\ ${ }^{23}$ Institut Agama Islam Negeri Sultan Amai Gorontalo \\ email: niksonkadir@gmail.com
}

\begin{abstract}
Abstrak
Penelitian bertujuan untuk menganalisis hubungan positif dan signifikan antara kompetensi profesional guru dan motivasi kerja dengan kinerja guru di SMP Negeri di Kecamatan Biluhu Kabupaten Gorontalo secara parsial maupun simultan.Penelitian ini merupakan penelitian kuantitatif.Sumber data dalam penelitian ini adalah data sekunder primer dari penyebaran kuesioner. Penelitian ini menggunakan jenis penelitian kuantitatif dengan pendekatan survei untuk mendapatkan informasi yang lengkap dan mendalam mengenai hubungan antara kompetensi profesional guru dan motivasi kerja dengan kinerja guru SMP negeri di kecamatan Biluhu kabupaten Gorontalo. adapun yang menjadi populasi pada penelitian ini adalah seluruh guru SMP negeri di Kecamatan Biluhu Kabupaten Gorontalo berjumlah orang 27, karena jumlah populasi dalam penelitian ini dibawah seratus orang, maka seluruh populasi dijadikan sebagai sampel dengan jumlah guru sebanyak 27 orang, Selanjutnya pengumpulan data penulis menggunakan angket, dan jenis analisis yang digunakan yaitu berupa analisis regresi berganda. Hasil penelitian ini menunjukan bahwa secara parsial maupun simultan kompetensi profesional guru dan motivasi kerja memiliki hubungan positif dan signifika dengan kinerja guru SMP negeri di kecamatan Biluhu kabupaten Gorontalo.nilai koefisien korelasi hubungan antara variabel bebas (kompetensi profesional guru dan motivasi kerja) dengan variabel terikat (kinerja guru) berada pada kategori hubungan yang kuat. Kemudian sisa nilai determinan terhadap kinerja guru dapat dari variabel penelitian yakni sebesar 0,931 (93,1\%).
\end{abstract}

Kata kunci: Kompetensi Profesional, Motivasi Kerja, Kinerja Guru 


\section{PENDAHULUAN}

Indikator suatu bangsa sangat ditentukan oleh tingkat sumber daya manusianya, dan indikator sumber daya manusia ditentukan oleh tingkat pendidikan masyarakatnya. Semakin tinggi sumber daya manusianya, maka semakin baik tingkat pendidikannya, dan demikian pula sebaliknya. Oleh sebab itu, indikator tersebut sangat ditentukan oleh kinerja guru. ${ }^{1}$ Kinerja adalah seluruh hasil yang diproduksi pada fungsi pekerjaan atau aktivitas khusus selama periode khusus. Kinerja keseluruhan pada pekerjaan adalah sama dengan jumlah atau rata-rata kinerja pada fungsi pekerjaan yang penting. Fungsi yang berkaitan dengan pekerjaan tersebut akan dilakukan dan tidak dilakukan dengan karakteristik kinerja individu. ${ }^{2}$

Dalam upaya meningkatkan mutu pendidikan, aspek utama yang ditentukan adalah kualitas guru. Maka kualitas guru harus di upayakan guna meningkatkan mutu pendidikan. Kualifikasi pendidikan guru sesuai dengan prasyarat minimal yang ditentukan oleh syarat-syarat seorang guru yang profesional. Guru professional yang dimaksud adalah guru yang berkualitas, berkompetensi, dan guru yang dikehendaki untuk mendatangkan motivasi belajar siswa supaya dalam proses belajar mengajar siswa akan semangat dan nantinya akan menghasilkan prestasi belajar siswa yang baik. ${ }^{3}$ Seorang guru di tuntut harus memiliki profesional. Karena profesionalisme guru merupakan kondisi, arah, nilai, tujuan dan kualitas suatu keahlian dan kewenangan dalam bidang pendidikan dan pembelajaran yang berkaitan dengan pekerjaan seseorang. Guru professional adalah guru yang mampu mendatangkan prestasi belajar serta mampu mempengaruhi proses belajar siswa, yang nantinya akan menghasilkan prestasi lebih baik.

Apabila para calon guru mempersiapkan diri dengan bekal pengetahuan yang cukup dengan selalu mengantisipasi tantangan-tantangan yang muncul, mereka akan dapat melaksanakan tugasnya dengan baik. Dalam proses pengajaran, mengajar merupakan suatu kegiatan yang memerlukan ketrampilan Professional dan banyak sekali yang harus dikerjakan oleh guru baik di dalam maupun diluar kelas, dalam mengambil beberapa keputusan. ${ }^{4}$ Dengan kondisi yang demikian diperlukan tenaga pendidikan yang berpotensi pada mutu (baik proses maupun hasil kerja), sebagaimana telah dijelaskan dalam undang-undang Republik Indonesia nomor 2 tahun 1989 bahwa setiap tenaga pendidikan berkewajiban untuk meningkatkan kemampuan professional sesuai tuntutan perkembangan ilmu pengetahuan dan teknologi serta perkembangan bangsa. ${ }^{5}$

Berbagai perubahan yang diakibatkan oleh kemajuan dalam bidang ilmu pengetahuan dan teknologi juga harus di antisipasi oleh guru.Dengan demikian Seorang guru tidak hanya menjadi sumber informasi tapi juga menjadi motivator. Dari uraian tersebut diatas bahwa keberhasilan pendidikan sebagian besar ditentukan oleh mutu April 2018

${ }^{1}$ Isjoni, "Kinerja Guru" dalam http://re-searchengines.com/isjonil2.html, diakses pada tanggal 22

${ }^{2}$ Rafik Issa Beekun, Etika Bisnis Islam, (Yogyakarta:Pustaka Pelajar, 2004) h. 120

${ }^{3}$ Sardiman, Interaksi \& Motivasi Belajar Mengajar (Jakarta: Raja Grafindo Persada, 2012), h.73.

${ }^{4}$ Rifai.M, Administrasi dan Supervisi Pendidikan, (Bandung: Jenmars, 1982), h.45

${ }^{5}$ UU RI No. 2 Tahun 1989, Tentang Sistem Pendidikan Nasional ,(Semarang:Aneka Ilmu, Pasal 131, 1989), h.14. 
profesional seorang guru. Guru yang profesional bukanlah guru yang hanya dapat mengajar dengan baik, tetapi juga guru yang dapat mendidik.

Seperti hal nya di SMP Negeri di kecamatan Biluhu kabupaten Gorontalo akibat sistem pengajaran terbaru yaitu tematik, membuat para guru pusing mengolah nilai dari hasil belajar, karena yang lebih ditekankan disini adalah sikap dari masing-masing siswa, Kurangnya guru disekolah ini membuat sebagian guru mengajar rangkap, selain itu persoalan lain terdapat guru yang mengajar mata pelajaran yang tidak sesuai dengan disiplin ilmu yang dimiliki hal ini yang membuat hasil-hasil ujian Nasional yang didapatkan oleh siswa di Ujian Nasional sangat rendah.

\section{KAJIAN TEORI}

\section{Kompetensi Profesional Guru}

Kompetensi profesional guru adalah seperangkat kemampuan yang harus dimiliki oleh guru agar ia dapat melaksanakan tugas mengajar. Adapun kompetensi profesional mengajar yang harus dimiliki oleh seorang yaitu meliputi kemampuan dalam merencanakan, melaksanakan, dan mengevaluasi sistem pembelajaran. ${ }^{6}$ Berdasarkan uraian tersebut maka konsep kompetensi profesional guru dapat diartikan sebagai kemampuan dasar melasksanakan tugas guru yang dapat dilihat dari kemampuan merencanakan program belajar mengajar, kemampuan melaksanakan atau mengelola proses belajar mengajar, dan kemempuan menilai proses belajar mengajar.

\section{Motivasi Kerja Guru}

Pengertian motivasi menurut Berelson dan Steiner adalah "suatu usaha sadar untuk memengaruhi perilaku seseorang supaya mengarah tercapainya tujuan organisasi.", Bagi seorang guru, tugas dan tanggung jawab tersebut terlihat pada aktivitas pembelajaran dan administrasi sekolah atau madrasah yang dikerjakan akibat dorongan dari dalam diri serta dorongan yang diberikan atasan dan lingkungannya. Maka motivasi kerja guru ada dua, yaitu:

a. Motivasi intrinsik, yaitu daya dorong yang timbul dari dalam diri masing-masing. Indikator motivasi intrinsik antara lain: adanya hasrat dan keinginan untuk melakukan kegiatan, adanya dorongan atau kebutuhan melakukan kegiatan, adanya harapan dan cita-cita. Pada motivasi intrinsik, setiap guru melaksanakan kerja karena kerja itu sendiri cukup bermakna bagi dirinya sendiri. Tujuan yang ingin dicapai terletak dalam kerja itu sendiri (menambah pengetahuan, ketrampilan, dan sebagainya).

b. Motivasi ekstrinsik, yaitu daya dorong yang datang dari luar diri seseorang, terutama dari organisasi tempatnya bekerja. Indikator motivasi ekstrinsik antara lain: panghargaan dan penghormatan atas diri, adanya lingkungan yang baik, dan adanya kegiatan yang menarik.

\footnotetext{
${ }^{6}$ Hamzah B Uno, Profesi Kependidikan; Problema, Solusi dan Reformasi Pendidikan di Indonesia, Bumi Aksara, Jakarta, 2007, h. 18.

7 Danang Sunyono, Teori, Kuesioner, dan Analisis Data Sumber Daya Manusia (Praktek Penelitian). (Yogyakarta: CAPS, 2012), 11.
} 


\section{Kinerja Guru}

\section{Pengertian Kinerja Guru}

Prestasi kerja adalah sesuatu hasil kerja yang dicapai seseorang dalam melaksanakan dan menyelesaikan pekerjaan yang dibebankan kepadanya." ${ }^{8}$ Jadi, dapat disimpulkan bahwa kinerja guru adalah hasil kerja secara kualitas dan kuantitas yang dicapai oleh seorang guru dalam melaksanakan tugasnya sesuai tanggung jawabnya. Kinerja guru merupakan prestasi nyata yang ditampilkan guru setelah menjalankan tugas dan perannya dalam organisasi. Kinerja yang baik merupakan tingkatan prestasi yang menunjukkan hasil guna kerja yang tinggi. Menurut Flippo, kinerja seseorang dapat diukur melalui:

a. Mutu kerja, berkaitan dengan ketepatan waktu, keterampilan dan kepribadian dalam melakukan pekerjaan.

b. Kualitas kerja, berkaitan dengan pemberian tugas-tugas tambahan yang diberikan oleh atasan kepada bawahannya.

c. Ketangguhan, berkaitan dengan tingkat kehadiran, pemberian waktu libur, dan jadwal keterlambatan hadir di tempat kerja.

d. Sikap, merupakan sikap yang ada pada karyawan yang menunjukkan seberapa jauh sikap tanggung jawab mereka terhadap sesama tema dengan atasan, dan seberapa jauh tingkat kerja sama dalam menyelesaikan pekerjaan. ${ }^{9}$

\section{METODOLOGI PENELITIAN}

Penelitian ini menggunakan jenis penelitian kuantitatif dengan pendekatan survei untuk mendapatkan informasi yang lengkap dan mendalam mengenai hubungan antara kompetensi profesional guru dan motivasi kerja dengan kinerja guru SMP negeri di kecamatan Biluhu kabupaten Gorontalo. adapun yang menjadi populasi pada penelitian ini adalah seluruh guru SMP negeri di Kecamatan Biluhu Kabupaten Gorontalo berjumlah orang 27 ,karena jumlah populasi dalam penelitian ini dibawah seratus orang, maka seluruh populasi dijadikan sebagai sampel dengan jumlah guru sebanyak 27 orang, Selanjutnya pengumpulan data penulis menggunakan angket, dan jenis analisis yang digunakan yaitu berupa analisis regresi berganda.

\section{HASIL PENELITIAN}

Penelitian ini merupakan penelitian kuantitatif yang dilakukan pada guru di Sekolah Menengah Pertama (SMP) Negeri di Kecamatan Biluhu Kabupaten Gorontalo dengan cara menyebar angket/kusioner penelitian kepada responden yang memenuhi standar sampel yang ditentukan oleh peneliti sebelumnya. Jumlah responden yang menjadi subjek penelitian sebanyak 27 responden yang memenuhi standar sampel penelitian.

\section{Statistik Deskriptif}

\section{a. Variabel Kompetensi profesional guru}

Variabel Kompetensi profesional guru terletak pada kriteria yang "baik" dengan skor 90,64\%. Hal ini menunjukan bahwa guru di Sekolah Menengah Pertama (SMP)

\footnotetext{
${ }^{8}$ Danang Sunyono, Teori, Kuesioner, dan Analisis Data Sumber Daya Manusia.., h.18.

${ }^{9}$ Ibid, h. 22.
} 
Negeri di Kecamatan Biluhu Kabupaten Gorontalo telah memiliki kompetensi profesional yang baik sesuai dengan standar yang telah ditetapkan. Hal ini tidak lepas dari adanya kemauan guru untuk memberikan pengajaran yang baik agar siswa memiliki kemampuan konsep dan hasil belajar yang maksimal. Dengan adanya kompetensi profesional ini akan mendorong jiwa profesional guru dalam menjalankan tugas dan fungsinya sebagai penutan siswa di sekolah

\section{b. Variabel Motivasi kerja}

Variabel Motivasi kerja terletak pada kriteria yang baik dengan skor 91,79\%. Hal ini menunjukan bahwa guru Sekolah Menengah Pertama (SMP) Negeri di Kecamatan Biluhu Kabupaten Gorontalo merasakan adanya semangat kerja yang tinggi yang timbul dari dalam dan luar. Dengan adanya motivasi kerja yang tinggi maka guru akan senantiasa bekerja sesuai dengan ketetapan yang berlaku sehingga semua pekerjaan dapat terlaksana dan mencapai hasil yang maksimal.

\section{c. Variabel Kinerja guru}

Variabel Kinerja guru terletak pada kriteria yang baik dengan skor 92,09\%. Hal ini menunjukan bahwa guru Sekolah Menengah Pertama (SMP) Negeri di Kecamatan Biluhu Kabupaten Gorontalo memiliki capaian hasil kerja yang maskimal dalam menjalankan perannya sebagai pengajar di sekolah. Kinerja yang baik ini akan menjadi sebuah katalisator untuk meningkatkan hasil belajar siswa serta berbagai harapa ideal sekolah baik dalam akademik dan non akademik maupun hal-hal adminsitratif yang harus dipenuhi oleh guru sekolah.

\section{Pengujian Asumsi Klasik}

a. Normalitas Residual

Hasil uji normalitas residual One Sample Kolmogorov Smirnov dapat dijabarkan berikut:

\section{Tabel 4.12: Hasil Uji Normalitas Residual}

\begin{tabular}{|ll|l|}
\hline & & Unstandardized Residual \\
\hline $\mathrm{N}$ & Mean & 27 \\
Normal Parameters ${ }^{\mathrm{a}, \mathrm{b}}$ & Std. Deviation & .0000000 \\
& Absolute & 4.64612103 \\
& Positive & .155 \\
Most Extreme Differences & Negative & .155 \\
& & -.116 \\
Kolmogorov-Smirnov Z & & .807 \\
Asymp. Sig. (2-tailed) & & .533 \\
\hline
\end{tabular}

Sumber: Data Olahan SPSS 21, 2019

Dari tabel di atas dapat diketahui bahwa pengujian normalitas data (Kolomogorov Smirnov) ditemukan bahwa nilai Kolomogorov Smirnov (KS) lebih kecil dibandingkan dengan nilai $Z$ tabel $(0,807<1,96)$. Sehingga dapat dikatakan bahwa data dalam penelitian ini memiliki nilai yang berdistribusi normal. 


\section{b. Pengujian Multikolinearitas}

Nilai Variance Inflation Factor (VIF) disajikan sebagai berikut ini:

Tabel 4.13: Pengujian Multikolinearitas

\begin{tabular}{|ll|l|l|}
\hline \multirow{2}{*}{ Model } & \multicolumn{3}{|l|}{ Collinearity Statistics } \\
\cline { 3 - 4 } & & Tolerance & VIF \\
\hline \multirow{2}{*}{1} & (Constant) & & \\
& Kompetensi Profesional & .167 & 5.972 \\
& Motivasi Kerja & .167 & 5.972 \\
\hline
\end{tabular}

Sumber: Olahan Data, 2019

Berdasarkan hasil pada tabel di atas diketahui bahwa variabel Kompetensi profesional guru memiliki nilai VIF sebesar 5,972 dan Motivasi kerja VIF-nya sebesar 5,972. Nilai tolernace tersebut lebih kecil dari angka standar 10. Sehingga dalam penelitian tidak terjadi gejala multikolinearitas atau memenuhi uji multikolinearitas.

\section{c. Pengujian Autokorelasi}

Hasil pengujian autokorelasi dengan metode Durbin Watson ditampilkan pada tabel 4.15 berikut ini:

Tabel 4.14: Hasil Pengujian Autokorelasi

\begin{tabular}{|l|l|l|}
\hline Model & Std. Error of the Estimate & Durbin-Watson \\
\hline 1 & 4.83584 & 1.949 \\
\hline
\end{tabular}

Sumber: Pengolahan Data SPSS 21, 2019

Berdasarkan tabel 4.15 di atas dapat dilihat bahwa nilai Durbin Watson pengujian sebesar 1,949. Berdasarkan pernyataan Santoso dan Ashari dikemukakan bahwa nilai Durbin Watson hitung yang memenuhi uji durbin watson jika terletak diantara nilai -2 sampai dengan $+2(-2<\mathbf{1 , 9 4 9}<+2)$. Sehingga dapat disimpulkan data dalam kedaan memenuhi uji autokorelasi. ${ }^{10}$

\section{d. Pengujian Heterokedastisitas Data}

Gambar 4.1 berikut merupakan hasil pengolahan data (Glejser) untuk menguji heterokedastisitas:

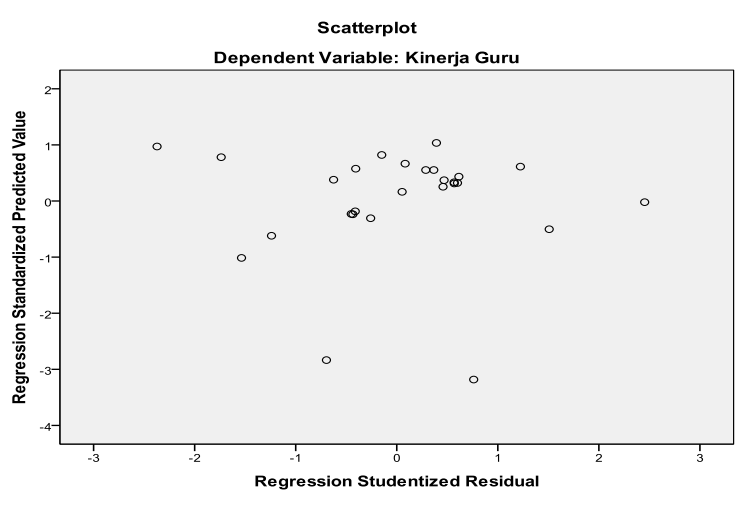

${ }^{10}$ Ashari, Purbayu Budi Santoso. Analisis Statistic dengan Microsoft Excel dan SPPS. (Yogyakarta, 2005), h.224 


\section{Gambar 4.1: Hasil Pengujian Heterokedastisitas}

Berdasarkan gambar di atas dapat diketahui bahwa titik-titik menyebar secara acak serta tersebar baik di atas maupun di bawah angka nol pada sumbu Y. Oleh karena itu maka dapat disimpulkan bahwa model regresi tidak terjadi heterokedastisitas. Untuk memperkuat hasil tersebut, maka perlu dilakukan uji heterokedastisitas dengan metode uji Glejser. Hasil pengujian heterokedastisitas dengan metode glejser disajikan pada tabel berikut ini:

Tabel 4.15: Hasil Pengujian Heterokedastistas Glejser

\begin{tabular}{|c|c|c|c|c|c|}
\hline Model & $\begin{array}{ll}\text { Sum } & \text { of } \\
\text { Squares } & \end{array}$ & df & Mean Square & $\mathbf{F}$ & Sig. \\
\hline $\begin{array}{l}\text { Regression } \\
\text { Residual } \\
\text { Total }\end{array}$ & $\begin{array}{l}1.534 \\
232.109 \\
233.643\end{array}$ & $\begin{array}{l}2 \\
24 \\
26\end{array}$ & $\begin{array}{l}.767 \\
9.671\end{array}$ & .079 & $.924^{\mathrm{b}}$ \\
\hline
\end{tabular}

Sumber: Data Olahan SPSS 21, 2018

Berdasarkan hasil pengolahan data di atas dapat diketahui bahwa nilai signifikansi atau Probability Value (P-Value) sebesar 0,924. Nilai signifikansi pengujian yang lebih besar dibandingkan dengan nilai alpha 0,05 . Jadi disimpulkan model regresi tidak terdapat masalah heterokedastisitas

\section{Analisis Regresi Berganda}

a. Penaksiran Model Regresi

Hasil analisis dengan bantuan program SPSS ditampilkan pada tabel 4.16 sebagai berikut:

Tabel 4.16: Hasil Analisis Regresi

\begin{tabular}{|ll|l|l|l|l|l|}
\hline \multirow{2}{*}{ Model } & \multicolumn{2}{|l|}{$\begin{array}{l}\text { Unstandardized } \\
\text { Coefficients }\end{array}$} & $\begin{array}{l}\text { Standardized } \\
\text { Coefficients }\end{array}$ & t & \multirow{2}{*}{ Sig. } \\
\cline { 2 - 5 } & B & Std. Error & Beta & & \\
\hline & (Constant) & -4.448 & 6.085 & & -.731 & .472 \\
1 & Kompetensi Profesional & .513 & .196 & .478 & 2.621 & .015 \\
& Motivasi Kerja & .470 & .181 & .474 & 2.599 & .016 \\
\hline
\end{tabular}

Sumber: Data Olahan SPSS 21, 2019

Berdasarkan hasil analisis diatas, model persamaan regresi linear berganda adalah:

$\hat{\mathbf{Y}}=-4,448+0,513 \beta X_{1}+0,470 \beta X_{2}+\varepsilon$

\section{b. Pengujian Parsial}

Berdasarkan tabel 4.16 pula dapat dilihat nilai $\mathrm{t}_{\text {-hitung }}$ yang diperoleh setiap variabel. Hasil positif atau negatif hanya menunjukan arah bukan menunjukan jumlah. Sehingga dalam interpretasi membandingkan $t_{\text {hitung }}$ dengan $t_{\text {tabel }}$ tidak perlu melihat angka negatifnya sebagai jumlah dari $t_{\text {hitung. }}$. Hasil dari nilai $t_{\text {hitung }}$ masing-masing variabel bebas dapat disajikan pada tabel berikut ini: 
Tabel 4.17: Hasil Pengujian Parsial

\begin{tabular}{lllll}
\hline No & Variabel & Nilai r (Korelasi) & $\begin{array}{l}\mathbf{t}_{\text {hitung }} \\
(\text { Pengaruh) }\end{array}$ & P-Value \\
\hline 0 & $\begin{array}{l}\text { Constant } \\
\text { Kompetensi }\end{array}$ & -0.731 & 0.472 \\
$1 \quad \begin{array}{l}\text { profesional } \\
\text { guru }\end{array}$ & 0,9103 & 2.621 & $0.015^{* *}$ \\
$2 \quad$ Motivasi kerja & 0,9100 & 2.599 & $0.016^{* *}$ \\
\hline $\begin{array}{l}\text { ns } \\
\text { Not Signifikan }\end{array}$ & & \\
$*$ Significant at the 0.1 level (2-tailed) \\
$* *$ Significant at the 0.05 level (2-tailed) \\
$* * *$ Significant at the 0.01 level (2-tailed)
\end{tabular}

Sumber: Data Olahan SPSS 21, 2019

Hasil pengujian hubungan Kompetensi profesional guru dan Motivasi kerja dengan Kinerja guru Sekolah Menengah Pertama (SMP) Negeri di Kecamatan Biluhu Kabupaten Gorontalo sebagai berikut:

1) Hubungan Kompetensi profesional guru dengan Kinerja guru Sekolah Menengah Pertama (SMP) Negeri di Kecamatan Biluhu Kabupaten Gorontalo

Berdasarkan analisis diperoleh korelasi Kompetensi profesional guru sebesar 0,9103 dan memiliki hubungan positif dengan Kinerja guru Sekolah Menengah Pertama (SMP) Negeri di Kecamatan Biluhu Kabupaten Gorontalo. Nilai tersebut berarti bahwa hubungan kompetensi profesional guru dengan kinerja guru sebesar 91,03\% berada pada kategori "hubungan yang kuat". Kemudian berdasarkan nilai ujit diperoleh tukey value sebesar 2,621 yang nilai signifikansi Kompetensi profesional guru $(0,015)$ lebih kecil dari nilai probabilitas 0,05 . Sehingga dapat disimpulkan bahwa Kompetensi profesional guru memiliki hubungan positif dan signifikan dengan Kinerja guru Sekolah Menengah Pertama (SMP) Negeri di Kecamatan Biluhu Kabupaten Gorontalo.

2) Hubungan Motivasi kerja dengan Kinerja guru Sekolah Menengah Pertama (SMP) Negeri di Kecamatan Biluhu Kabupaten Gorontalo

Berdasarkan analisis diperoleh korelasi Motivasi kerja sebesar 0,9100 dan memiliki hubungan positif dengan Kinerja guru Sekolah Menengah Pertama (SMP) Negeri di Kecamatan Biluhu Kabupaten Gorontalo. Nilai tersebut berarti bahwa hubungan motivasi kerja dengan kinerja guru sebesar $91,00 \%$ berada pada kategori "hubungan yang kuat". Kemudian berdasarkan nilai uji-t diperoleh tukey value sebesar 2,599 yang nilai signifikansi motivasi kerja $(0,016)$ lebih kecil dari nilai probabilitas 0,05. Sehingga dapat disimpulkan bahwa Motivasi kerja memiliki hubungan positif dan signifikan dengan kinerja guru Sekolah Menengah Pertama (SMP) Negeri di Kecamatan Biluhu Kabupaten Gorontalo. 


\section{c. Pengujian Simultan (Uji F)}

Hasil pengujian model regresi (simultan) dengan bantuan program SPSS 21 ditampilkan pada tabel 4.18 berikut ini:

Tabel 4.18: Hasil Pengujian Simultan

\begin{tabular}{|c|c|c|c|c|c|}
\hline Model & $\begin{array}{ll}\text { Sum } & \text { of } \\
\text { Squares } & \end{array}$ & df & Mean Square & $\mathbf{F}$ & Sig. \\
\hline $\begin{array}{l}\text { Regression } \\
\text { Residual } \\
\text { Total }\end{array}$ & $\begin{array}{l}3637.842 \\
561.247 \\
4199.089\end{array}$ & $\begin{array}{l}2 \\
24 \\
26\end{array}$ & $\begin{array}{l}1818.921 \\
23.385\end{array}$ & 77.780 & $.000^{\mathrm{b}}$ \\
\hline
\end{tabular}

Sumber: Olahan Data, 2019

Berdasarkan tabel di atas didapat nilai $\mathrm{F}_{\text {-hitung }}$ penelitian ini sebesar 77,780 dengan nilai signifikansi atau probabilitas sebesar 0,000. nilai probabilitas yang diperoleh dari pengujian lebih kecil dari nilai alpha 0,05 . Sehingga kompetensi profesional guru dan motivasi kerja secara bersama-sama memiliki hubungan positif dan signifikan dengan kinerja guru Sekolah Menengah Pertama (SMP) Negeri di Kecamatan Biluhu Kabupaten Gorontalo.

\section{d. Pengujian Koefisien Determinasi}

Nilai koefisien determinasi merupakan suatu nilai yang besarnya berkisar antara 0\%-100\%. Untuk mengetahui besarnya koefisien determinasi $\left(\mathrm{R}^{2}\right)$ dapat dilihat pada tabel 4.17 berikut:

Tabel 4.19: Koefisien Determinasi

\begin{tabular}{|l|l|l|l|l|}
\hline Model & R & R Square & Adjusted R Square & $\begin{array}{l}\text { Std. Error of the } \\
\text { Estimate }\end{array}$ \\
\hline 1 & $.931^{\mathrm{a}}$ & .866 & .855 & 4.83584 \\
\hline
\end{tabular}

Sumber: Data Olahan SPSS, 2019

Berdasarkan tabel di atas diperoleh nilai koefisien korelasi dari variabel penelitian yakni sebesar $0,931(93,1 \%)$. Hal ini berarti bahwa hubungan antara variabel bebas (kompetensi profesional guru dan motivasi kerja) dengan variabel terikat (kinerja guru) berada pada kategori hubungan yang kuat. Hasil analisis koefisien determinasi Adjusted $R$ Square adalah sebesar 0,855. Nilai ini menunjukan bahwa sebesar 85,5\% variabilitas Kinerja guru Sekolah Menengah Pertama (SMP) Negeri di Kecamatan Biluhu Kabupaten Gorontalo dapat dijelaskan oleh Kompetensi profesional guru dan Motivasi kerja sedangkan sisanya sebesar $14,5 \%$ dijelaskan oleh variabel lain yang tidak diteliti dalam penelitian ini. 


\section{PEMBAHASAN}

1. Hubungan Kompetensi profesional guru dengan Kinerja guru Sekolah Menengah Pertama (SMP) Negeri di Kecamatan Biluhu Kabupaten Gorontalo

Guru yang profesional tentu saja akan berdampak pada peserta didik, hal tersebut sebagaimana pernyataan dari Uno bahwa kemampuan professional guru adalah seperangkat kemampuan yang harus dimiliki oleh seorang guru agar ia dapat melaksanakan tugas mengajar. ${ }^{11}$ Adapun kompetensi professional mengajar yang harus dimiliki oleh seorang yaitu meliputi kemampuan dalam merencanakan, melaksanakan, dan mengevaluasikan sistem pembelajaran, serta kemampuan guru dalam mengembangkan sistem pembelajaran. Dengan demikian adanya kompetensi profesional guru maka siswa akan semakin aktif dalam belajar dan akan mampu menghasilkan nilai dan hasil belajar yang baik.

Hasil penelitian secara parsial menunjukan bahwa kompetensi profesional guru memiliki hubungan positif dan signifikan dengan Kinerja guru Sekolah Menengah Pertama (SMP) Negeri di Kecamatan Biluhu Kabupaten Gorontalo. Kemudian dari nilai korelasi ditemukan bahwa hubungan kompetensi profesional guru dengan kinerja guru sebesar $91,03 \%$ berada pada kategori "hubungan yang kuat". Sebagai upaya untuk meningkatkan kompetensi profesionalisme guru maka sebaiknya guru lebih aktif dalam mengikuti berbagai kegiatan yang dapat meningkatkan kompetensi seperti seminar, musyawarah guru mata pelajaran bahkan menempuh pendidikan formal lanjutan serta banyak membaca dan mengupdate berbagai peraturan dan regulasi terbaru mengenai kompetensi profesional guru.

Hasil dari pengujian ini sejalan dengan pernyataan dari Kunandar, guru yang profesional akan tercermin dalam pelaksanaan pengabdian tugas-tugas yang ditandai dengan keahlian baik dalam materi maupun dalam metode. Selain itu, juga ditunjukkan melalui tanggung jawabnya dalam melaksanakan seluruh pengabdiannya. Guru yang profesional hendaknya mampu memikul dan melaksanakan tanggung jawab sebagai guru kepada peserta didik, orang tua, masyarakat, bangsa, negara, dan agamanya. Guru professional mempunyai tanggung jawab pribadi, sosial, intelektual, moral, dan spiritual sehingga akan meningkatkan hasil capain kerjanya. Menjadi seorang guru bukanlah pekerjaan yang gampang, seperti yang dibayangkan sebagian orang, dengan bermodal penguasaan materi dan menyampaikannya kepada siswa sudah cukup, hal ini belumlah dapat dikategori sebagai guru yang memiliki pekerjaan profesional, karena guru yang profesional, mereka harus memiliki berbagai keterampilan, kemampuan khusus, mencintai pekerjaannya, menjaga kode etik guru, dan lain sebagainya. ${ }^{12}$

${ }^{11}$ Hamzah B. Uno, Teori Motivasi dan Pengukurannya (Analisis di Bidang Pendidikan). (Jakarta: Bumi Aksara, 2010),h. 68-69

${ }^{12}$ Kunandar. Guru Profesional : Implementasi Kurikulum Tingkat Satuan Pendidikan (KTSP) dan Sukses dalam Sertifikasi Guru. (Jakarta : Rajagrafindo Persada. 2007) h. 47 


\section{Hubungan Motivasi kerja dengan Kinerja guru Sekolah Menengah Pertama (SMP) Negeri di Kecamatan Biluhu Kabupaten Gorontalo}

Motivasi kerja merupakan suatu dorongan untuk melakukan suatu pekerjaan. Motivasi kerja erat hubungannya dengan capaian kinerja. Pada dasarnya motivasi kerja seseorang itu berbeda-beda. Ada motivasi kerjanya tinggi dan ada motivasi kerjanya rendah, bila motivasi kerjanya tinggi maka akan berpengaruh pada kinerja yang tinggi dan sebaliknya jika motivasinya rendah maka akan menyebabkan capaian kinerja yang dimiliki seseorang tersebut rendah. Jika guru mempunyai motivasi kerja tinggi maka ia akan bekerja dengan keras, tekun, senang hati, dan dengan dedikasi tinggi sehingga hasilnya sesuai dengan tujuan yang ingin dicapai. .

Hasil penelitian secara parsial menunjukan bahwa motivasi kerja memiliki hubungan positif dan signifikan dengan kinerja guru Sekolah Menengah Pertama (SMP) Negeri di Kecamatan Biluhu Kabupaten Gorontalo. Kemudian dari nilai korelasi ditemukan bahwa hubungan motivasi kerja dengan kinerja guru sebesar 91,00\% berada pada kategori "hubungan yang kuat". Dalam upaya untuk meningkatkan motivasi kerja guru maka sebaiknya adanya motivasi kepada guru yang sangat krusial diberikan oleh kepala sekolah. Kemudian motivasi juga dapat diupayakan melalui penciptaan iklim dan budaya kerja yang kondusif bagi guru.

Motivasi kerja juga dapat memberikan energi yang menggerakkan segala potehsi yang ada, menciptakan keinginan yang tinggi dan luhur, serta meningkatkan kebersamaan dalam mencapai tujuan organisasi dengan kata lain motivasi kerja menurut pengertian tersebut merupakan suatu kondisi yang berpengaruh membangkitkan, mengarahkan dan memelihara perilaku yang berhubungan dengan lingkungan kerja. Keterkaitan antara motivasi kerja dengan kinerja guru sebagaimana dijelaskan oleh Uno bahwa motivasi merupakan kegiatan yang melibatkan, menyalurkan, dan memelihara perilaku manusia. Motivasi merupakan subjek yang penting bagi manajer karena manajer bekerja melalui dan dengan orang lain. Oleh karena itu jika guru yangmempunyai motivasi kerja yang tinggi biasanya mempunyai kinerja yang tinggi. ${ }^{13}$

3. Hubungan Kompetensi profesional guru dan Motivasi kerja dengan Kinerja guru Sekolah Menengah Pertama (SMP) Negeri di Kecamatan Biluhu Kabupaten Gorontalo

Semua kegiatan yang dilakukan di sekolah pada akhirnya akan bermuara pada peningkatan kualitas peserta didik sehingga guru adalah orang yang memiliki posisi terdepan dan sentral di dalam pelaksanaan proses pembelajaran. Oleh karena itu, kinerja guru selalu menjadi perhatian karena merupakan faktor penentu dalam meningkatkan prestasi belajar dan berperan dalam meningkatkan kualitas lulusan sehingga kinerja dan totalitas dedikasi dan loyalitas pengabdiannya akan menjadi pusat perhatian di sekolah. Dengan adanya kompetensi dan motivasi yang tinggi maka akan berdampak pada kinerja dari seorang guru. Kinerja dalam melaksanakan kegiatan sehari-hari perlu diubah cara bekerjasama dari bagaimana melihat atau meninjau kinerja itu sendiri. Dengan demikian

${ }^{13}$ Hamzah B. Uno, Teori Motivasi dan Pengukurannya (Analisis di Bidang Pendidikan,. h. 67 
pimpinan dan pegawai yang bertanggung jawab langsung dalam pelaksanaan kinerja harus pula dievaluasi secara periodik. Dalam kenyataannya terdapat 2 (dua) faktor yang mempengaruhi pencapaian kinerja adalah faktor kemampuan dan faktor motivasi (motivation). ${ }^{14}$

Hasil penelitian secara simultan menunjukan bahwa Kompetensi profesional guru dan motivasi kerja secara bersama-sama memiliki hubungan positif dan signifikan dengan kinerja guru Sekolah Menengah Pertama (SMP) Negeri di Kecamatan Biluhu Kabupaten Gorontalo. nilai koefisien korelasi dari variabel penelitian yakni sebesar 0,931 (93,1\%). Hal ini berarti bahwa hubungan antara variabel bebas (kompetensi profesional guru dan motivasi kerja) dengan variabel terikat (kinerja guru) berada pada kategori hubungan yang kuat.

Kinerja adalah hasil atau taraf kesuksesan yang dicapai seseorang dalam bidang pekerjaannya menurut kriteria tertentu dievaluasi oleh orang-orang tertentu terutama atasan pegawai yang bersangkutan. Kinerja Guru adalah kemampuan dan usaha guru untuk melaksanakan tugas pembelajaran sebaik-baiknya dalam perencanaan program pengajaran, pelaksanaan kegiatan pembelajaran dan evaluasi hasil pembelajaran. Kinerja guru yang dicapai harus berdasarkan standar kemampuan profesional selama melaksanakan kewajiban sebagai guru di sekolah. ${ }^{15}$ Kemampuan dan motivasi kerja seseorang dalam melaksanakan tugas-tugasnya menentukan hasil kerja seseorang dan pada akhirnya akan berpengaruh terhadap pencapaian tingkat organisasi secara keseluruhan. Setelah jelas hubungan antara kemampuan, motivasi dan kinerja pegawai, maka dapat disimpulkan bahwa kinerja pegawai adalah hasil yang dicapai dari kemampuan dan motivasi yang dimiliki oleh pegawai. Dengan demikian kemampuan dan motivasi kerja memiliki pengaruh positif terhadap terhadap kinerja seorang guru.

\section{KESIMPULAN}

Berdasarkan hasil penelitian dan pembahasan di atas, maka dapat ditarik simpulan bahwa:

1. Kompetensi profesional guru memiliki hubungan positif dan signifikan dengan Kinerja guru Sekolah Menengah Pertama (SMP) Negeri di Kecamatan Biluhu Kabupaten Gorontalo. Kemudian dari nilai korelasi ditemukan bahwa hubungan kompetensi profesional guru dengan kinerja guru sebesar $91,03 \%$ berada pada kategori "hubungan yang kuat".

2. Motivasi kerja memiliki hubungan positif dan signifikan dengan kinerja guru Sekolah Menengah Pertama (SMP) Negeri di Kecamatan Biluhu Kabupaten Gorontalo. Kemudian dari nilai korelasi ditemukan bahwa hubungan motivasi kerja dengan kinerja guru sebesar $91,00 \%$ berada pada kategori "hubungan yang kuat".

3. Kompetensi profesional guru dan motivasi kerja secara bersama-sama memiliki hubungan positif dan signifikan dengan kinerja guru Sekolah Menengah Pertama

${ }^{14}$ A.A Anwar Prabu Mangkunegara. Evaluasi Kinerja Sumber Daya Manusia. (Bandung: PT. Refika Aditama. 2012). h. 67

${ }^{15}$ Yulia Racmawati. Pengaruh Kepemimpinan Kepala Sekolah Terhadap Kinerja Guru. (Jurnal Pendidikan Ekonomi IKIP Veteran Semarang Vol. 01 No. 01, Juni. 2013). h 21 
(SMP) Negeri di Kecamatan Biluhu Kabupaten Gorontalo. nilai koefisien korelasi dari variabel penelitian yakni sebesar 0,931 (93,1\%). Hal ini berarti bahwa hubungan antara variabel bebas (kompetensi profesional guru dan motivasi kerja) dengan variabel terikat (kinerja guru) berada pada kategori hubungan yang kuat. Kemudian sisa nilai determinan terhadap kinerja guru dapat dijelaskan oleh variabel lain yang tidak diteliti dalam penelitian ini seperti dimensi kompetensi guru lainnya, lingkungan sekolah, peran pimpinan atau kepala sekolah, komitmen kerja guru serta budaya organisasi yang diterapkan di sekolah.

\section{SARAN}

Berdasarkan simpulan yang telah diuraikan di atas, maka peneliti memberikan saran sebagai berikut:

1. Sebagai upaya untuk meningkatkan kompetensi profesionalisme guru maka sebaiknya guru lebih aktif dalam mengikuti berbagai kegiatan yang dapat meningkatkan kompetensi seperti seminar, musyawarah guru mata pelajaran bahkan menempuh pendidikan formal lanjutan serta banyak membaca dan mengupdate berbagai peraturan dan regulasi terbaru mengenai kompetensi profesional guru.

2. Dalam upaya untuk meningkatkan motivasi kerja guru maka sebaiknya adanya motivasi kepada guru yang sangat krusial diberikan oleh kepala sekolah. Kemudian motivasi juga dapat diupayakan melalui penciptaan iklim dan budaya kerja yang kondusif bagi guru.

3. Untuk meningkatkan kinerja guru maka sebaiknya guru terus memaksimalkan berbagai potensi guru dan membina hubungan baik dengan masyarakat sekolah maupun orang tua siswa agar kinerja guru dalam pendidikan ssiwa di sekolah dapat meningkat dengan optimal.

\section{DAFTAR PUSTAKA}

A.A Anwar Prabu Mangkunegara. Evaluasi Kinerja Sumber Daya Manusia. (Bandung: PT. Refika Aditama. 2012).

Ashari, Purbayu Budi Santoso. Analisis Statistic dengan Microsoft Excel dan SPPS. Yogyakarta, 2005

Beekun, Rafik Issa. Etika Bisnis Islam, Yogyakarta:Pustaka Pelajar, 2004.

Isjoni, "Kinerja Guru" dalam http://re-searchengines.com/isjoni12.html, diakses pada tanggal 22 April 2018.

Kunandar. Guru Profesional : Implementasi Kurikulum Tingkat Satuan Pendidikan (KTSP) dan Sukses dalam Sertifikasi Guru. (Jakarta : Rajagrafindo Persada. 2007)

Rifai. M, Administrasi dan Supervisi Pendidikan, (Bandung: Jenmars, 1982)

Sardiman, Interaksi \& Motivasi Belajar Mengajar (Jakarta: Raja Grafindo Persada, 2012) 
Sunyono, Danang. Teori, Kuesioner, dan Analisis Data Sumber Daya Manusia (Praktek Penelitian). Yogyakarta: CAPS, 2012.

Uno, Hamzah B. Profesi Kependidikan; Problema, Solusi dan Reformasi Pendidikan di Indonesia, (Bumi Aksara, Jakarta, 2007)

Uno, Hamzah B. Teori Motivasi dan Pengukurannya (Analisis di Bidang Pendidikan). Jakarta: Bumi Aksara, 2010.

UU RI No. 2 Tahun 1989, Tentang Sistem Pendidikan Nasional,(Semarang:Aneka Ilmu, pasa 131,1989$)$

Yulia Racmawati. Pengaruh Kepemimpinan Kepala Sekolah Terhadap Kinerja Guru. (Jurnal Pendidikan Ekonomi IKIP Veteran Semarang Vol. 01 No. 01, Juni. 2013). 